\title{
MENINGKATKAN KREATIVITAS MATEMATIKA MELALUI MODEL PEMBELAJARAN PROJECT BASED LEARNING DAN DAMPAKNYA TERHADAP SIKAP SERTA HASIL BELAJAR
}

\author{
Heri Herwanto \\ Fakultas Ilmu Komputer Universitas Kuningan \\ Jl. Cut Nyak Dien No.63 Cijoho Kuningan \\ e-mail: hery210@gmail.com
}

\begin{abstract}
The study, entitled "Enhancing Creativity Learning Mathematics through Project Based Learning Model and Its Impact on Attitude and Learning Outcomes" conducted on students of the second semester study program Information Systems Faculty of Computer Science University of Brass. This research is motivated by the fact that the survey results indicate a lack of creativity of mathematics, consequently affect the poor attitude and mathematics learning outcomes. The study aims to analyze whether there was an effect Implementation Project Based Learning Model Learning to creativity, attitude and student results. The research method used mixmethode, where quantitative data and qualitative data presented to strengthen each other and interpreted based on the facts and findings that occurred during the study. Based on the research results obtained by the fact that the amount of influence the implementation of Project Based Learning Model Learning for Creativity, Attitude and Learning Outcomes are sinifikan. improvement of learning outcomes based on the value of the gain shows the medium category, and the response to the application of the Model Student Learning Project Based Learning is positive. Based on the findings, with the implementation of Project Learning Model Based Learning, students gain learning experience complete and intact because it is done step by step based on the concepts of mathematics to produce a project that could be used for community needs.
\end{abstract}

Keywords: $\quad$ Learning Model Project Based Learning, Creativity, Attitudes, Learning Outcomes

\section{PENDAHULUAN}

Mata kuliah Matematika merupakan mata kuliah wajib yang harus ditempuh oleh setiap mahasiswa di seluruh program studi ilmu komputer. Hal ini bisa dipahami bahwa perkembangan sains dan teknologi tidak lepas dari peranan matematika.
Mata kuliah Matematika yang menjadi dasar bagi pemahaman ilmu komputer diantaranya adalah Kalkulus, Logika, Matematika Diskrit, Al jabar Linear, Statistika, dan Metode Numerik serta beberapa mata kuliah matematika terapan langsung terhadap ilmu komputer. 
Mata kuliah Statistika merupakan salah satu cabang dari ilmu Matematika terapan, bahkan di negara-negara maju ilmu statistika telah sejak lama berkembang pesat sejalan dengan kemajuan ilmu ekonomi dan teknik. bahkan kemajuan suatu negara ditentukan oleh sejauh mana negara itu dapat menerapkan ilmu statistika dalam perencanaan pembangunan dan memecahkan masalah-masalah pembangunan (Boediono \& Koster,2008:2).

Permasalahan yang muncul pada pembelajaran matematika adalah masih rendahnya hasil belajar dan persentase ketuntasan mengikuti perkuliahan masih kurang dari 100\%. Penulis mengumpulkan beberapa data dan fakta mengenai hasil belajar statistika di lingkungan Fakultas Ilmu Komputer dengan hasil sebagai berikut.

Tabel 1.1

Data Nilai Statistika Tahun Pembelajaran 2010 - 2014 Prodi SI-S1

\begin{tabular}{c|c|c|c}
\hline $\begin{array}{c}\text { Tahun } \\
\text { Pembelajar } \\
\text { an }\end{array}$ & $\begin{array}{c}\text { Jumlah } \\
\text { mahasis } \\
\text { wa }\end{array}$ & $\begin{array}{c}\text { Skor } \\
\text { rata- } \\
\text { rata }\end{array}$ & $\begin{array}{c}\text { Ketu } \\
\text { ntasa } \\
\mathrm{n}\end{array}$ \\
\hline $2010-2011$ & 67 & 62 & $\begin{array}{c}92,54 \\
\% \\
87,50 \\
\%\end{array}$ \\
$2011-2012$ & 56 & 64 & $\begin{array}{c}75,70 \\
\%\end{array}$ \\
$2012-2013$ & 114 & 63 & $\begin{array}{c}86,70 \\
\%\end{array}$ \\
$2013-2014$ & 105 & 65,5 & \multicolumn{2}{|c}{} \\
\hline
\end{tabular}

(Sumber : Daftar Nilai Prodi SI S1)

Solusi untuk mengatasi permasahan tersebut adalah dengan menerapkan model pembelajaran
Project Based Learning (PjBL). Hal ini sejalan dengan Penelitian yang dilakukan oleh Lindawati (2013) menunjukan bahwa model project based learning dapat meningkatkan kreativitas dan hasil belajar pada siswa kelas X MAN I Kebumen, Hal ini dibuktikan dengan data hasil test pada setiap siklus yang mengalami peningkatan. Apabila kita kaitkan pada bidang statistika, maka pemilihan model Project Based Learning (PjBL) sangat sudah tepat. Hal ini berdasarkan penelitian yang dilakukan oleh Ardhi Prabowo (2012) menunjukan bahwa Pembelajaran bebasis proyek telah dapat meningkatkan pemahaman mahasiswa atas permasalahan statistika. Hal tersebut ditunjukkan dengan dicapainya indikator kinerja, bahwa mahasiswa dapat menyimpulkan, kasus-kasus yang terjadi dalam statistika antara lain: (1) data, (2) metode pengumpulan data dan kevalidannya, (3) analisis data, dan (4) ketepatan pengambilan simpulan.

Berdasarkan data, fakta dan masalah yang telah dipaparkan, maka penulis tertarik untuk melakukan penelitian dengan judul "Meningkatkan Kreativitas Matematika melalui Model Pembelajaran Project Based Learning dan Dampaknya pada Sikap serta Hasil Belajar."

Dengan mengacu pada latar belakang masalah, maka rumusan masalahnya adalah sebagai berikut.

1. Apakah peningkatan kreativitas belajar mereka yang pembelajarannya dengan model Project Based Learning (PjBL) lebih baik dari mereka yang 
pembelajarannyadengan

konvensional?

2. Apakah dampak pada hasil belajar yang pembelajarannya menggunakan model Project Based Learning (PjBL) lebih baik dari pada yang pembelajaraanya menggunakan konvensional?

3. Adakah hubungan kreativitas belajar terhadap hasil belajar?

4. Bagaimana hubungan sikap belajar terhadap kreativitas belajar?

5. Bagaimana hubungan sikap belajar terhadap hasil belajar?

6. Bagaimana tanggapan mahasiswa terhadap penerapan model pembelajaran Project Based Learning (PjBL)?

Tujuan Penelitiannya sebagai berikut:

1. Menganalisis peningkatan kreativitas belajar yang pembelajarannya dengan model Project Based Learning (PjBL) dibandingkan dengan mereka yang pembelajarannya dengan konvensional.

2. Menganalisis dampak pada hasil belajar yang pembelajarannya menggunakan model Project Based Learning (PjBL) dibandingkan dengan mereka yang pembelajaraanya menggunakan konvensional.

3. Menganalisis hubungan kreativitas belajar terhadap hasil belajar.

4. Menganalisis hubungan sikap belajar terhadap kreativitas belajar.

5. Menganalisis hubungan sikap belajar terhadap hasil belajar.

6. Menganalisis tanggapan mahasiswa terhadap penerapan model pembelajaran Project Based Learning (PjBL).
Hasil penelitian ini diharapkan nantinya akan dapat memberikan manfaat kepada berbagai pihak, diantaranya:

1. Bagi mahasiswa, memberikan pemahaman dan pengalaman yang berharga dengan keterlibatannya secara aktif dalam proses pembelajaran matematika statistika melalui penerapan model pembelajaran PjBL sehingga mahasiswa mampu menerapkannya pada sains dan teknologi.

2. Bagi dosen, penerapan model pembelajaran PjBL dalam pembelajaran matematika statistika sebagai suatu alternatif meningkatkan sikap positif, kreativitas dan hasil belajar matematika statistika.

3. Bagi lembaga pendidikan, hasil penelitian ini diharapkan dapat meningkatkan kualitas lulusan yang siap bersaing didunia kerja melalui peningkatan hasil belajar mahasiswa.

\section{LANDASAN/KAJIAN TEORI}

Kreativitas adalah hasil dari interaksi antara individu dan lingkungannya seseorang mempengaruhi dan dipengaruhi oleh lingkungan dimana ia berada dengan demikian baik berubah di dalam individu maupun di dalam lingkungan dapat menunjang atau dapat menghambat upaya kreatif (Munandar, 1995).

Sikap merupakan kecenderungan pola tingkah laku individu untuk berbuat sesuatu dengan cara tertentu terhadap orang, benda atau gagasan. 
Sikap dapat diartikan sekelompok keyakinan dan perasaan yang melekat tentang objek tertentu dan kecenderungan untuk bertindak terhadap objek tersebut dengan cara tertentu (Calhoun, 1978). Menurut Robert R.Gabe (Siskandar, 2008), Sikap merupakan kesiapan yang terorganisir yang mengarahkan atau mempengaruhi tanggapan individu terhadap obyek.

Hasil belajar adalah kemampuan yang dimiliki siswa setelah ia menerima pengalaman belajarnya. Hasil belajar mempunyai peranan penting dalam proses pembelajaran. Proses penilaian terhadap hasil belajar dapat memberikan informasi kepada guru tentang kemajuan siswa dalam upaya mencapai tujuan-tujuan belajarnya melalui kegiatan belajar.

Pembelajaran Berbasis Proyek (Project Based Learning/PjBL) adalah metoda pembelajaran yang menggunakan proyek/kegiatan sebagai media. Peserta didik melakukan eksplorasi, penilaian, interpretasi, sintesis, dan informasi untuk menghasilkan berbagai bentuk hasil belajar. Pembelajaran Berbasis Proyek merupakan metode belajar yang menggunakan masalah sebagai langkah awal dalam mengumpulkan dan mengintegrasikan pengetahuan baru berdasarkan pengalamannya dalam beraktifitas secara nyata. (Kemendikbud, 2013).

Penelitian yang dilakukan oleh Y.Doppelt (2003), menyimpulkan bahwa penggunaan Project based learning meningkatkan motivasi dan citra diri disemua tingkatan dan menyimpulkan bahwa dalam tiga tahun kegiatan menunjukkan peningkatan jumlah siswa yang berprestasi rendah pada akhir SMP dan selesai SMA dengan memenuhi prasyarat untuk masuk ketingkat pendidikan tingkat lanjut.

\section{METODE PENELITIAN}

Metode yang digunakan pada penelitian ini adalah metode campuran (Mixed Method) dengan tipe Explanatory Sequetial Design. Metode campuran (Mixed Method) tipe Explanatory Sequetial Design adalah metode penggabungan antara penelitian kualitatif dengan penelitian kuantitatif, dimana perlakuan dari suatu tindakan kualitatif akan dibuktikan dengan data kuantitatif yang dihasilkan atau mungkin bisa berlaku juga sebagai kebalikannya. Desain penelitian dengan menggunakan model Experimental Design. Alur dari desain penelitian ini dimulai dengan memberikan pre-test kemudian dilanjutkan dengan pemberian perlakuan/treatment yaitu penerapan model pembelajaran Project Based Learning setelah itu diberikan post-test (Sugiono: 2009). Secara sederhana desain penelitian dapat dilihat pada bagan berikut :

$$
\begin{array}{llll}
\text { A : } & \text { O } & \text { X } & \text { O } \\
\text { B : } & \text { O } & & \text { O }
\end{array}
$$

Bagan 3.2 Desain Penelitian Keterangan :

A : Kelas Eksperimen

B : Kelas Konvensional

$\mathrm{O}$ : Tes (pre-test dan postest) 
$\mathrm{X}$ : Perlakuan (treatment) pembelajaran Project Based Learning

Instrumen penelitian merupakan alat yang digunakan untuk memperoleh atau mengumpulkan data-data selama kegiatan penelitian dilakukan. Instrumen penelitian berupa tes dan non tes. Jenis instrumen berupa tes adalah lembar soal pretest (sebelum mendapat perlakuan) dan postest (setelah mendapat perlakuan). Sedangkan instumen berupa non tes adalah lembar observasi, lembar kuesioner, daftar partisipan, pedoman wawancara, daftar studi dokumen, Draf laporan dari focus group discussion.

Sebelum menguji hipotesis, sebagai tahap awal dari proses analisis data maka dilakukan uji normalitas data dengan menggunakan Kolmogorof-Smirnov. (Sugiyono, 2012). Apabila data tersebut normal maka Pada tahap selanjutnya dilakukan teknik analisis data berdasarkan hipotesis penelitian sebagai berikut :

1. Untuk menganalisis peningkatan kreativitas belajar setelah diterapkan model pembelajaran Project Based Learning maka digunakan uji gain Pada nilai pretest dan postest yang diperoleh dari kelas PJBL dan membandingkanya dengan kelas Konvensional (data kuantitatif).

Untuk analisis kualitatif dilakukan pemaparan secara deskripsi tentang temuan-temuan yang terjadi pada penerapan model pembelajaran Project Based Learning (PjBL) terhadap peningkatan kreativitas belajar.
2. Untuk menganalisis dampak terhadap peningkatan hasil belajar setelah diterapkan model pembelajaran Project Based Learning maka digunakan uji gain Pada nilai pretest dan postest yang diperoleh dari kelas PJBL dan membandingkanya dengan kelas Konvensional (data kuantitatif).

Untuk analisis kualitatif dilakukan pemaparan secara deskripsi tentang temuan-temuan yang terjadi pada penerapan model pembelajaran Project Based Learning (PjBL) terhadap peningkatan hasil belajar.

3. Untuk menganalisis hubungan kreativitas terhadap hasil balajar, maka digunakan analisis korelasi (data kuantitatif) dan pemaparan secara deskripsi tentang temuan-temuan yang terjadi pada hubungan sikap terhadap kreativitas belajar (data kualitatif) .

4. Untuk menganalisis hubungan sikap belajar terhadap kreativitas belajar, maka digunakan analisis regresi linear (data kuantitatif) dan pemaparan secara deskripsi tentang temuan-temuan yang terjadi pada pengaruh sikap terhadap kreativitas belajar (data kualitatif) .

5. Untuk menganalisis hubungan sikap belajar terhadap hasil belajar, maka digunakan analisis regresi linear (data kuantitatif) dan pemaparan secara deskripsi tentang temuantemuan yang terjadi pada pengaruh sikap dan kreativitas terhadap hasil belajar (data kualitatif) .

6. Untuk menganalisis tanggapan mahasiswa terhadap pelaksanaan penerapan model pembelajaran 
Project Based Learning, maka digunakan lembar kuesioner dengan menggunakan skala Likert.

\section{HASIL PENELITIAN DAN} PEMBAHASAN

Untuk menganalisis peningkatan kreativitas belajar dengan Model Project Based Learning dan Konvensional, maka digunakan uji gain dengan hasil sebagai berikut:

Hasil Uji Gain Kreativitas Belajar

\begin{tabular}{|c|c|c|c|c|}
\hline Model & $\begin{array}{c}\text { Uji } \\
\text { Statistik }\end{array}$ & $\begin{array}{l}\text { Pre } \\
\text { test }\end{array}$ & $\begin{array}{l}\text { Post } \\
\text { test }\end{array}$ & $\begin{array}{l}\mathrm{Ga} \\
\text { in }\end{array}$ \\
\hline \multirow{5}{*}{ PJBL } & Rata-rata & $\begin{array}{l}50 \\
84\end{array}$ & $\begin{array}{c}75,7 \\
8\end{array}$ & $\begin{array}{l}0, \\
51\end{array}$ \\
\hline & $\begin{array}{c}\text { Skor } \\
\text { Minimum }\end{array}$ & $\begin{array}{l}30 \\
00\end{array}$ & $\begin{array}{c}58,3 \\
3\end{array}$ & $\begin{array}{l}0, \\
10\end{array}$ \\
\hline & $\begin{array}{c}\text { Skor } \\
\text { Maksimu } \\
\text { m }\end{array}$ & $\begin{array}{l}70 \\
00\end{array}$ & $\begin{array}{c}100 \\
00\end{array}$ & $\begin{array}{c}1, \\
00\end{array}$ \\
\hline & Standar & 9,8 & 10,0 & 0 , \\
\hline & Deviasi & 2 & 1 & 18 \\
\hline \multirow{4}{*}{$\begin{array}{c}\text { Konven } \\
\text { sional }\end{array}$} & Rata-rata & $\begin{array}{l}44, \\
91\end{array}$ & $\begin{array}{c}66,7 \\
5\end{array}$ & $\begin{array}{l}0, \\
39\end{array}$ \\
\hline & $\begin{array}{c}\text { Skor } \\
\text { Minimum }\end{array}$ & $\begin{array}{l}25 \\
00\end{array}$ & $\begin{array}{c}50,0 \\
0 \\
\end{array}$ & $\begin{array}{l}0, \\
18\end{array}$ \\
\hline & $\begin{array}{c}\text { Skor } \\
\text { Maksimu } \\
\mathrm{m} \\
\end{array}$ & $\begin{array}{l}65, \\
00\end{array}$ & $\begin{array}{c}85,0 \\
0\end{array}$ & $\begin{array}{l}0, \\
67\end{array}$ \\
\hline & $\begin{array}{l}\text { Standar } \\
\text { Deviasi }\end{array}$ & $\begin{array}{c}8,2 \\
3\end{array}$ & 8,98 & $\begin{array}{l}0, \\
14\end{array}$ \\
\hline
\end{tabular}

Untuk menganalisis dampak terhadap peningkatan hasil belajar dari model Project Based Learning dan konvensional, maka digunakan uji gain dengan hasil sebagai berikut:

Hasil Uji Gain Hasil Belajar

\begin{tabular}{c|c|c|c|c}
\hline Model & $\begin{array}{c}\text { Uji } \\
\text { Statistik }\end{array}$ & $\begin{array}{c}\text { Pret } \\
\text { est }\end{array}$ & $\begin{array}{c}\text { Post } \\
\text { test }\end{array}$ & $\begin{array}{c}\text { Ga } \\
\text { in }\end{array}$ \\
\hline PJBL & Rata-rata & 49, & 74,1 & 0, \\
\hline
\end{tabular}

\begin{tabular}{c|c|r|r|r}
\multicolumn{1}{c|}{} & & 44 & 9 & 49 \\
\cline { 2 - 5 } & Skor & 30, & 50,0 & 0, \\
Minimum & 00 & 0 & 15 \\
\cline { 2 - 5 } & Skor & & & \\
Maksimu & 78, & 93,0 & 0, \\
$\mathrm{~m}$ & 00 & 0 & 80 \\
\hline \multirow{4}{*}{ Konven } & Standar & 13, & 12,0 & 0, \\
\cline { 2 - 5 } & Deviasi & 63 & 8 & 19 \\
\hline & & 47, & 69,9 & 0, \\
& Rata-rata & 69 & 1 & 40 \\
\cline { 2 - 5 } & Skor & 30, & 55,0 & 0, \\
\cline { 2 - 5 } & Minimum & 00 & 0 & 04 \\
\hline Skor & & & \\
& Maksimu & 75, & 87,0 & 0, \\
& m & 00 & 0 & 80 \\
\cline { 2 - 5 } & Standar & 12, & & 0, \\
& Deviasi & 32 & 9,65 & 19 \\
\hline
\end{tabular}

Hubungan Kreativitas terhadap Hasil belajar

Analisis Kuantitatif dilakukan dengan Korelasi Pearson dan dilakukan dengan bantuan Software SPSS dengan hasil sebagai berikut

\section{Correlations}

\begin{tabular}{|c|c|c|c|}
\hline & & $\begin{array}{l}\text { Kreativita } \\
\text { s_Belajar }\end{array}$ & $\begin{array}{l}\text { Hasil_ } \\
\text { Belajar }\end{array}$ \\
\hline & Pearson & 1 &, $451^{* *}$ \\
\hline Kreat & Correlatio & & \\
\hline ivitas & $\mathrm{n}$ & & \\
\hline Bela & Sig. (2- & & 010 \\
\hline jar & tailed) & & \\
\hline & $\mathrm{N}$ & 32 & 32 \\
\hline & Pearson & $451^{* * *}$ & 1 \\
\hline
\end{tabular}

Hasil Correlatio

\begin{tabular}{|c|c|c|c|}
\hline jar & $\begin{array}{c}\text { Sig. (2- } \\
\text { tailed) }\end{array}$ & ,010, & \\
\hline & $\mathrm{N}$ & 32 & 32 \\
\hline
\end{tabular}


Hubungan Sikap Belajar terhadap Kreativitas Belajar

Analisis kuantitatif dilakukan dengan Regresi Linier dan dengan bantuan Software SPSS dengan hasil sebagai berikut

\begin{tabular}{|c|c|c|c|c|}
\hline \multicolumn{5}{|c|}{ Model Summary } \\
\hline $\begin{array}{c}\text { Mode } \\
1\end{array}$ & $\mathrm{R}$ & $\begin{array}{c}\mathrm{R} \\
\text { Squar } \\
\mathrm{e}\end{array}$ & $\begin{array}{c}\text { Adjuste } \\
\text { d R } \\
\text { Square }\end{array}$ & $\begin{array}{l}\text { Std. } \\
\text { Error of } \\
\text { the } \\
\text { Estimat } \\
\text { e }\end{array}$ \\
\hline 1 & $\begin{array}{r}737 \\
\text { a }\end{array}$ &, 543 &, 528 & 2,392 \\
\hline
\end{tabular}

a. Predictors: (Constant), Sikap_Belajar

Hubungan Sikap Belajar terhadap Hasil Belajar

Analisis Kuantitatif dilakukan dengan Regresi linierdan dilakukan dengan bantuan Software SPSS dengan hasil sebagai berikut

\section{Model Summary}

\begin{tabular}{|c|c|c|c|c|}
\hline $\begin{array}{c}\text { Mode } \\
1\end{array}$ & $\mathrm{R}$ & $\begin{array}{c}\mathrm{R} \\
\text { Squar } \\
\mathrm{e}\end{array}$ & $\begin{array}{c}\text { Adjuste } \\
\text { d R } \\
\text { Square }\end{array}$ & $\begin{array}{l}\text { Std. } \\
\text { Error of } \\
\text { the } \\
\text { Estimat } \\
\mathrm{e}\end{array}$ \\
\hline 1 & $\begin{array}{r}, 541 \\
\text { a }\end{array}$ & ,293 & ,270 & 10,328 \\
\hline
\end{tabular}

a. Predictors: (Constant), Sikap_Belajar

Analisis kuntitatif mengenai tanggapan mahasiswa terhadap penerapan model pembelajaran yaitu dengan menggunakan bantuan Software Exel dengan cara menginfutkan jumlah skor pada tiap butir pernyataan dan menghitung jumlah total dan rata- ratanya. adapun hasilnya adalah sebagai berikut

Tabel. Skor Rata-rata Tiap Variabel

\begin{tabular}{ccccc}
\hline $\begin{array}{c}\text { N } \\
\text { o }\end{array}$ & $\begin{array}{c}\text { Jenis } \\
\text { Variab } \\
\text { el }\end{array}$ & $\begin{array}{c}\text { Rata- } \\
\text { rata } \\
\text { Skor }\end{array}$ & $\begin{array}{c}\text { Kateg } \\
\text { ori }\end{array}$ & $\begin{array}{c}\text { Keter } \\
\text { angan }\end{array}$ \\
\hline 1 & PjBL & 3,92 & $\begin{array}{c}\text { Ragu- } \\
\text { Setuju }\end{array}$ & $\begin{array}{c}\text { Positi } \\
\mathrm{p}\end{array}$ \\
\hline & $\begin{array}{c}\text { Kreativ } \\
\text { itas }\end{array}$ & 3,75 & $\begin{array}{c}\text { Ragu- } \\
\text { Setuju }\end{array}$ & $\begin{array}{c}\text { Positi } \\
\mathrm{p}\end{array}$ \\
\hline & $\begin{array}{c}\text { Sikap } \\
\text { Belajar }\end{array}$ & 4,06 & Setuju & $\begin{array}{c}\text { Positi } \\
\mathrm{p}\end{array}$ \\
\hline & $\begin{array}{c}\text { Hasil } \\
\text { Belajar }\end{array}$ & 4,14 & Setuju & $\begin{array}{c}\text { Positi } \\
\mathrm{p}\end{array}$ \\
\hline
\end{tabular}

\section{SIMPULAN DAN SARAN}

Berdasarkan hipotesis, pengolahan data kuantitif dan kualitatif serta temuantemuan, maka kesimpulannya sebagai berikut:

1. Peningkatan kreativitas dengan model pembelajaran Project Based Learning (PjBL) lebih baik dari model konvensional. Hal ini di buktikan dari tiap tahapan tugas yang diberikan, ternyata mahasiswa dapat menyelesaikan dengan ide-ide kreatif yang dituangkan melalui pengamatan dilapangan secara lengkap dan kolaboratif.

2. Dampak terhadap peningkatan hasil belajar dengan model pembelajaran Project Based Learning (PjBL) lebih baik dari model konvensional. Hal ini dibuktikan oleh adanya fakta bahwa peningkatan hasil belajar dengan model $\quad \mathrm{PjBL}$ dapat disertai dengan laporan makalah dari sebuah projek yang dilakukan secara kelompok membawa hasil yang memuaskan 
3. Terdapat hubungan yang kuat kreativitas belajar terhadap hasil belajar. Hal ini dibuktikan dari fakta yang terjadi bahwa kreativitas yang tinggi akan menambah pengalaman mahasiswa dan menuntut untuk membaca berbagai referensi yang pada gilirannya meningkatkan hasil belajar.

4. Terdapat hubungan yang kuat sikap belajar terhadap kreativitas. Hal ini dibuktikan sikap yang positip yang ditampakkan oleh mahasiswa melalui pembelajaraan yang disiplin, sikap menerima dan merespon balik terhadap tugastugas dapat memunculkan nilai kreativitas.

5. Terdapat hubungan yang kuat sikap belajar hasil belajar. Hal ini dibuktikan dengan suatu sikap yang ulet, datang tepat waktu dan bertindak sesuai dengan rencana dapat menambah kepercayaan diri dalam mengerjakan tugas projek dan dapat mempresentasikannya dengan berbagai referensi yang relevan, hal ini berpengaruh terhadap hasil belajar.

6. Adanya respon yang positif dari mahasiswa terhadap penerapan model pembelajaran PjBL. Hal ini dibuktikan dari fakta bahwa mahasiswa cukup antusias mengerjakan tugas projectnya dan mempresentasikannya dengan tepat waktu.

\section{DAFTAR PUSTAKA}

Arikunto, S. (2002). Prosedur Penelitian. Jakarta: Rineka Cipta. (2006). Prosedur Penelitian Suatu Model Praktik. Jakarta: Rineka Cipta.

Boediono dan Koster,W. (2008). Teori dan Aplikasi, Statistika dan Probabilitas, Bandung:PT.Remaja Rosda Karya (ISBN:979-692-125-1)

Creswell, J.W. (2008). Educational Research: Ptoming, Conducting, and Evaluating Quantitative 307 and Qualitative Research (3rd ed.). Upper Saddle River, NJ: Merrill.

Dopplet, Y. (2003). Implementation and Assessment of Project-Based Learning in a Flexible Environment, artikel dalam International Journal of Technology and Design Education 13, 255-272. Netherlands: Kluwer Academic Publishers.

Lindawati, dkk. (2013). Penerapan Model Pembelajaran Project Based Learning Untuk Meningkatkan Kreativitas Siswa Man I Kebumen (Radiasi.Vol.3.No.1). Purworejo : FKIP-Universitas Muhamadiyah Purworejo

Model Pembelajaran Berbasis Proyek (2013). Badan Pengembangan 
Sumber Daya Manusia

Pendidikan dan Kebudayaan dan Penjaminan Mutu Pendidikan.

Jakarta: Kementrian Pendidikan dan Kebudayaan

Prabowo, A. (2012). Pembelajaran Berbasis Proyek Untuk Meningkatkan Pemahaman

Mahasiswa atas Permasalahan Statistika pada Perkuliahan Studi Kasus dan Seminar. Semarang: FMIPA-UNNES Jurnal Kreano ISSN: 20862334 Vol.3)

Slameto. (1995). Belajar Dan FaktorFaktor Yang Mempengaruhi. Jakarta: Rineka Cipta.

Sudjana. (1989). Dasar-dasar Proses Belajar Mengajar. Bandung : Sinar Baru Algensido Offset.
Sudijono, A. (2007). Pengantar Evaluasi Pendidikan, Jakarta: PT Raja Grafindo Persada.

Sugiyono, (2010). Metode Penelitian Pendidikan, Bandung: Alfabeta.

Sumarmo, U. (2010). Berpikir dan Disposisi Matematik: Apa, Mengapa, dan Bagimana Mengembangkan Pada Peserta Didik, Makalah. FMIPA UPI..

Widyantini, Th. ( 2014). Penerapan Model Pembelajaran Project Based Learning dalam Materi Pola Bilangan Kelas VII. PPPPTK. Matematika: Yogyakarta 
